\title{
The evolution of parasitism in Nematoda
}

\author{
MARK BLAXTER* and GEORGIOS KOUTSOVOULOS \\ Institute of Evolutionary Biology, The University of Edinburgh, Edinburgh EH9 37T, UK
}

(Received 19 February 2014; revised 16 April 2014; accepted 16 April 2014; first published online 25 Fune 2014)

\author{
SUMMARY
}

Nematodes are abundant and diverse, and include many parasitic species. Molecular phylogenetic analyses have shown that parasitism of plants and animals has arisen at least 15 times independently. Extant nematode species also display lifestyles that are proposed to be on the evolutionary trajectory to parasitism. Recent advances have permitted the determination of the genomes and transcriptomes of many nematode species. These new data can be used to further resolve the phylogeny of Nematoda, and identify possible genetic patterns associated with parasitism. Plant-parasitic nematode genomes show evidence of horizontal gene transfer from other members of the rhizosphere, and these genes play important roles in the parasite-host interface. Similar horizontal transfer is not evident in animal parasitic groups. Many nematodes have bacterial symbionts that can be essential for survival. Horizontal transfer from symbionts to the nematode is also common, but its biological importance is unclear. Over 100 nematode species are currently targeted for sequencing, and these data will yield important insights into the biology and evolutionary history of parasitism. It is important that these new technologies are also applied to free-living taxa, so that the pre-parasitic ground state can be inferred, and the novelties associated with parasitism isolated.

Key words: Nematoda, nematodes, parasitism, evolution, genome, symbiont, Wolbachia, phylogeny, horizontal gene transfer.

\section{THE DIVERSITY OF THE NEMATODA}

Nematoda is an ancient and biologically diverse phylum of moulting animals. They range in size from $0.2 \mathrm{~mm}$ to over $6 \mathrm{~m}$, and can be found in most habitats, including within and on host animals and plants (Blaxter and Denver, 2012). In many marine and terrestrial sediments they are the most abundant group in terms of individuals (Platonova and Gal'tsova, 1976), and while only approximately 23000 species have been described (J. Hallan, unpublished; https:// insects.tamu.edu/research/collection/hallan/), the true species-level diversity may be 1 million or more (Lambshead, 1993). Most terrestrial plants and larger animals are associated with at least one species of parasitic nematode, and most of the human population experiences nematode parasitism during their lives (with perhaps one quarter to one third of the global population infected at any time). Estimates of the number of species of parasitic nematode per host suggest that there may be of the order of 25000 nematode parasites just of vertebrates, most of which remain undescribed (Dobson et al. 2008). Nematodes are thus important regulators of plant and animal production. Understanding the evolutionary origins of plant and animal parasitism, and the mechanisms by which parasites locate and invade their hosts, avoid host immunity, and acquire nutrition, are important goals for not only basic, but also for

\footnotetext{
* Corresponding author: The Ashworth Laboratories, The King's Buildings, Edinburgh EH9 3JT, UK. E-mail: mark.blaxter@ed.ac.uk.
}

medical and veterinary science. In this paper we discuss the changes in our understanding of the diversity and relationships of nematodes, and of the biology of their parasitic habits, that have been brought about by study of their genes and, increasingly, genomes.

Nematoda are part of Ecdysozoa, a superphylum of animals first defined through analyses of molecular markers (Aguinaldo et al. 1997). Support for Ecdysozoa as distinct from other groupings of protostome taxa is less strong from analyses of morphological characters (Nielsen, 2001). Ecdysozoan phyla are characterized by the presence of a cuticle that is periodically moulted during the life cycle, though the specifics of the molecular nature of the cuticle and the orchestration of ecdysis differ between phyla. Other shared features adduced as evidence of relatedness between these phyla include an absence of cilia in adults, and in many members the presence of a triradiate pharynx. The Ecdysozoa in turn comprises two groups, the Panarthropoda (phyla Tardigrada, Onychophora and Arthropoda) and Cycloneuralia (Nematoda, Nematomorpha, Priapulida, Kinorhyncha and Loricifera). Within Cycloneuralia, which may be paraphyletic with respect to Panarthropoda, Nematoda are consistently placed as sisters to Nematomorpha in morphological and molecular analyses (SchmidtRhaesa, 1997; Dunn et al. 2008).

Nematomorpha are a fascinating group of obligate parasites of terrestrial (Gordioidea) and marine (Nectonematoidea) arthropods. These 'horsehair worms' have a parasitoid life cycle, with the larval 
A

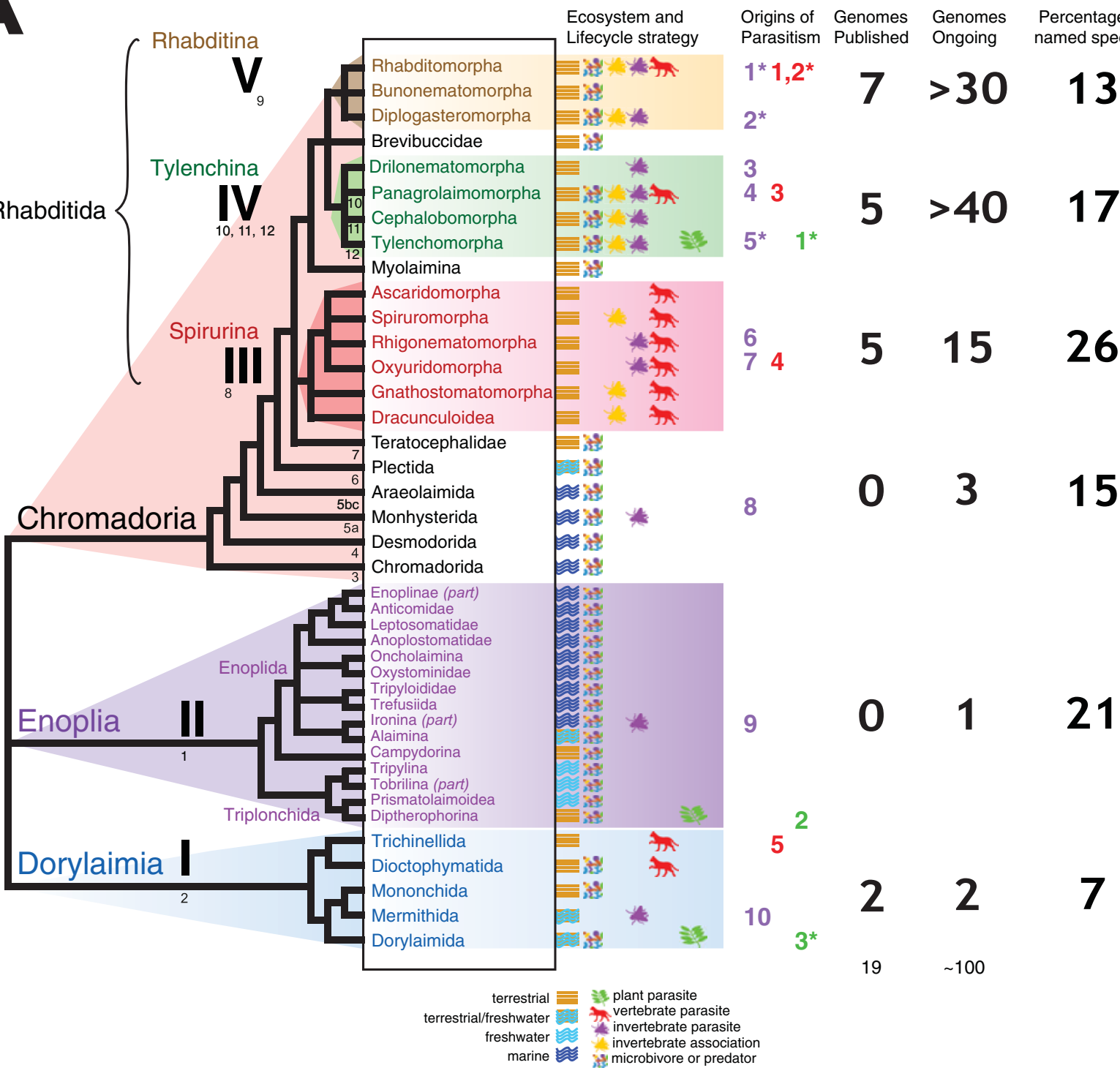

B

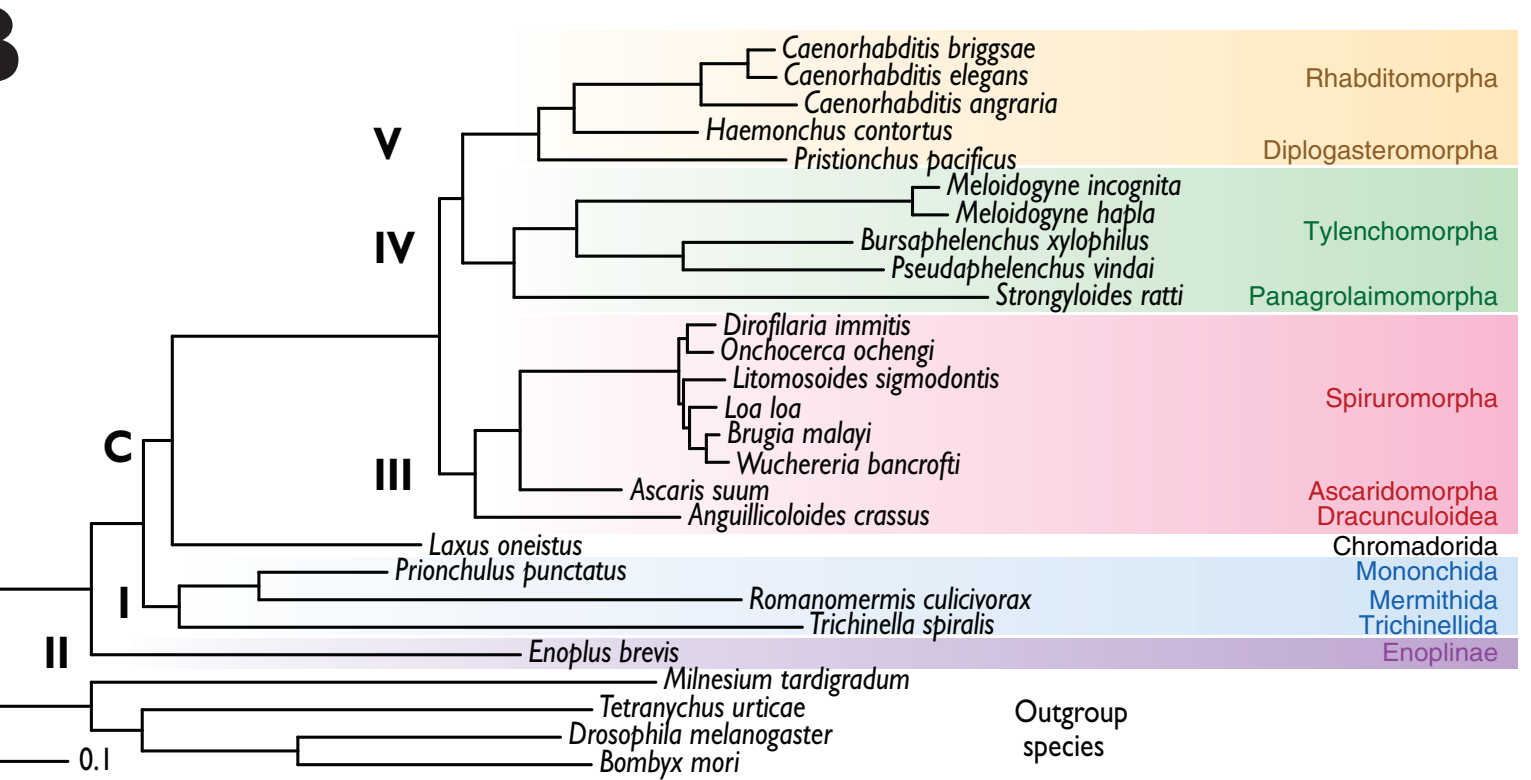

Fig. 1. The phylogenetic structure of the Nematoda and the origins of parasitism (A) A cartoon of the phylogenetic structure of the Nematoda, based on nuclear small subunit ribosomal RNA analyses and interpretation of taxon relationships derived from morphology (De Ley and Blaxter, 2004; Blaxter and Denver, 2012). Taxon systematic 
stages residing within the body cavities of their arthropod hosts, which they kill when they emerge. The adult sexual stages are free-living in pelagic (Nectonematoidea) or sediment (Gordioidea) habitats. Infection of the next host is by ingestion of eggs, often glued to vegetation eaten by the hosts (Hanelt and Janovy, 1999). The generalized life cycle of nematomorphs is very similar to that of mermithid nematodes, which also have marine and terrestrial members, and which also infect their hosts as larvae but have free-living adult stages. The placement of a phylum wherein all members are parasites as sister to all of Nematoda raises the interesting question of whether the ancestor to all nematodes was a parasite (with biology similar to nematomorphs or mermithids), and that the extant free-living groups in Nematoda are reversions from this ancestrally parasitic state. This question has historically been answered in the negative, and molecular data support this conclusion, because free-living nematodes arise basally to Mermithida in Nematoda. The similarity in lifestyle is thus most likely to be homoplasious (i.e. has arisen independently by convergent evolution).

The molecular systematics of the Nematoda have been explored for nearly 20 years (Blaxter et al. 1998; Kampfer et al. 1998), and comprehensive analyses of the breadth of diversity of the phylum now converge on a stable phylogeny (Meldal et al. 2007; Holterman et al. 2009; van Megen et al. 2009; Bik et al. 2010). These analyses have largely used the nuclear small subunit ribosomal RNA gene (nSSU), as it combines features of conservation and change that are informative over deep timescales. New genomic data are being brought to bear on the phylogenetics of Nematoda, and revisions of the tree may still be necessary (see below). While most traditional analyses suggested a bipartite division of the phylum, into 'Adenophorea' (largely marine, but also including terrestrial plant and animal parasites) and 'Secernentea' (largely terrestrial, and including many animal and plant parasites), the molecular analyses show three major divisions (Fig. 1A). The 'Adenophorea' are split between these three divisions, and 'Secernentea' are a subgroup of one. The new phylogeny was sytematized by De Ley and Blaxter (2002, 2004).

Nematoda comprises the subclasses Enoplia, Dorylaimia and Chromadoria (De Ley and Blaxter,
2002, 2004). In nSSU analyses the branching order of these three groups is unresolved, though there are hints that Enoplia may be the earliest-branching of the three (van Megen et al. 2009; Blaxter et al. 2014). The inability of nSSU to robustly distinguish the branching order and thus the root of the phylum is due to lack of strong signal, exacerbated by the phylogenetic distance to the nearest outgroup taxa (other Ecdysozoa, which likely last shared a common ancestor well before the Cambrian, over $540 \mathrm{My}$ ago).

It is generally argued that Nematoda has a marine origin (see Fig. 1A). The Enoplia are largely marine, and mostly free-living. They are the commonest nematodes in marine sediments, and dominate deepsea ecosystems where they feed on diatoms and marine algae. Members of Enoplia are also found in brackish and fresh water, and on land, including plant parasites. The Dorylaimia are freshwater or terrestrial nematodes and include major groups of plant and animal parasites. The Chromadoria includes a large number of marine groups, and a major terrestrial radiation that includes plant and animal parasites. In Chromadoria the terrestrial taxa appear to have arisen from marine ancestors, but the situation in the other subclasses is less clear. Dorylaimia has few truly marine taxa, and in Enoplia molecular phylogenies place the terrestrial/ freshwater Triplonchida as sister to the remaining (marine) Enoplida.

THE MULTIPLE ORIGINS OF PARASITISM WITHIN THE NEMATODA

Nematodes exhibit a wide range of relationships with other species. Parasitism is a common way of life, and a large proportion of nematode species may be parasites. Poulin has usefully classified the different kinds of parasitic relationships between species into a spectrum of life-habit modes (Poulin, 2011; Poulin and Randhawa, 2013). Some relationships are phoretic: the nematodes use another species to aid dispersal to new sites (Bovien, 1937). Phoretic associations can be very specific, as in Rhabditis stammeri, associates of burying beetles (Nicrophorus spp.), which have a complex response to the beetle life cycle that assures their presence in emerging adults by entering and diapausing in the hind guts of mature larvae before they pupate (Richter, 1993).

names are given for the major nodes in the phylogeny. Clades I, II, C, III, IV and V were first defined in Blaxter $e t$ al. (1998). Helder and colleagues revised the numbering of clades (Holterman et al. 2006; van Megen et al. 2009), and their schema is given in smaller Arabic numerals beneath the relevant branches. For each ordinal/subordinal group named, the ecosystem and trophic habits are indicated by small icons. For the major clades, the numbers of published genomes, genomes in progress and the proportion of named species (Hallan, 2007) are given. (B) The utility of large scale nematode genome data for phylogenetic analyses. A phylogeny of Nematoda derived from 181 protein coding genes from 23 nematode species, and four ecdysozoan taxa as outgroup. The alignment was subjected to analysis with PhyloBayes (Lartillot et al. 2009), and all nodes had posterior probability of 1.00. The major clades in Rhabditida are resolved, and Enoplia is recovered at the base of Nematoda. The figure is adapted from Blaxter et al. (2014). 
Other phoretic relationships are less specific, and dispersal stages can be found attached to many different transport hosts. In most cases, the dispersal stage is a third stage juvenile (J3, or L3 for larva). The costs to the phoretic host are hard to measure, but may be significant in heavily colonized hosts, or where the associate extracts some nutrition from its carrier. Many plant parasitic nematodes, particularly the migratory endoparasites, could be classified as microherbivores (Poulin and Randhawa, 2013), as their ecology is similar to that of an ungulate browsing on bushy plants. However these nematodes do induce specific cell responses in host plants, and thus the relationship is more than just browsing. Some intestinal parasites, such as the Rhigonematida of millipedes (Hunt, 1996), feed on gut contents or other nematode parasites rather than on host tissue, and might even be classed as commensals.

Independent origins of the parasitic habit can be validated by molecular phylogenetic placement of parasitic taxa and their free-living relatives (Blaxter et al. 1998; Dorris et al. 1999). With the current available molecular data we can define three origins of plant parasitism, 10 of parasitism of a wide range of non-vertebrates and five of parasitism of vertebrate hosts across the three subclasses (Fig. 1 and Table 1). Many additional events of acquisition of parasitic lifestyles could be proposed. For example, Sudhaus has suggested at least 20 independent events of acquisition of parasitism of insects in Nematoda (Sudhaus, 2008). Enoplia has the fewest parasitic species, while Chromadoria (and Rhabditida within Chromadoria) has the most. All parasitic groups appear to have a terrestrial or limnic origin. The sole enoplian animal parasite, Ironus macrocephalum (Ironidae), was described from the earthworm Pheretima wendessiana in New Guinea (Pierantoni, 1916). Other Ironidae are freshwater species.

There are some striking phylogenetic associations between non-vertebrate and vertebrate parasites. The Strongylomorpha (in Rhabditina), a major group of gut and airway parasites of vertebrates, are sisters to the Heterorhabditidae. Heterorhabditis species are entomopathogens that invade the haemocoel of insect larvae, and release a symbiotic bacterium that kills the host. Similarly, the mammal-parasitic Strongyloidoidae (Tylenchina; Panagrolaimomorpha) are related to the entomopathogenic Steinernematidae. Steinernema species also invade the haemocoel, and use a bacterial symbiont (a different group of species) to kill their hosts. The entomopathogens show convergence in life style, and are phylogenetically associated with a transition to vertebrate parasitism. However, there is no evidence that the vertebrate parasites utilize symbiotic bacteria during their life cycle. One model for the origin of the vertebrateparasitic Strongylomorphs and Strongyloidoids is that they represent host capture by an ancestral terrestrial, entomopathogenic or entomoparasitic species, and subsequent radiation in the new host groups. Not all associations with arthropods necessarily lead to full parasitism, as there are several nematode groups (notably the Diplogasteromorpha in Rhabditina) where many species are phoretic or necromenic associates of arthropods but very few parasites have been found.

The Spirurina (Chromadoria; Rhabditida) are all parasites, mostly in vertebrates. Many Spirurina utilize vector hosts to facilitate transit from one definitive host to another, but there are also groups (Ascaridomorpha, Oxyruidomorpha) that do not use intermediate hosts. Some groups utilize multiple intermediate hosts, with Gnathostomatomorpha passaging through both a first, crustacean paratenic host and a second, fish host before establishing in carnivorous mammals. Surprisingly, in the new Spirurina phylogeny, groups with a simple, direct life cycle appear to be derived from a radiation of groups that have vector hosts. Gnathostomatomorpha arise basally, and Ascaridomorpha and Oxyuridomorpha have their origins as sisters to other vectorborne groups such as Spiruromorpha (Nadler et al. 2007; Laetsch et al. 2012). Loss and gain of vector hosts within groups are common, and radical shift of vector species while continuing to use similar definitive hosts is a common feature of related parasites. For example, the Onchocercinae, parasitizing rodents, ungulates and primates, utilize mosquitoes, tabanid flies, black flies and mites as vectors. Two groups of arthropod parasites are nested within the otherwise vertebrate parasitic Spirurina (Rhigonematomorpha are gut parasites of large millipedes, and many Oxyuridomorpha are parasites of arthropods), and thus there must have been at least two independent transitions from vertebrate to arthropod parasitism (possibly by neotenic development in vector species) in these groups. Interestingly, Philometra obturans, a dracunculoid parasite of pike, has been observed to grow to sexual maturity in copepod intermediate hosts when the fish definitive host is absent (Moravec and de Buron, 2013).

\section{COMMON THEMES}

There are few common themes in the parasitic lifestyles of nematodes. One is that the stage at which parasites transition from a free-living portion of the life cycle to the parasitic portion (or vice versa) is usually the J3/L3 stage, the same stage usually involved in phoretic associations (Sudhaus, 2010). Most rhabditid parasites first invade their hosts as J3, and mermithids exit their hosts as J3. The diapausing J3 stage of the free-living nematode Caenorhabditis elegans (not a parasite, but a species that has phoretic associations with terrestrial isopods) is particularly resistant to environmental insult, and is used as a model for the infective $\mathrm{J} 3$ of parasitic nematodes 
Table 1. Origins of parasitism in the Nematoda ${ }^{a}$

\begin{tabular}{|c|c|c|c|c|}
\hline $\begin{array}{l}\text { Origin } \\
\text { number }^{b}\end{array}$ & Nematode group & Host group(s) & Parasitic types sensu Poulin ${ }^{c}$ & Comments \\
\hline \multicolumn{5}{|c|}{ Non-vertebrate hosts } \\
\hline $\begin{array}{l}1 \text { (multiple } \\
\text { events) }\end{array}$ & $\begin{array}{l}\text { Heterorhabditis, Phasmarhabditis, } \\
\text { Rhabditis (and others) }\end{array}$ & $\begin{array}{l}\text { Hexapoda, } \\
\text { Mollusca, } \\
\text { Clitellata }\end{array}$ & $\begin{array}{l}\text { Parasitoid, Castrator, Directly transmitted } \\
\text { parasite }\end{array}$ & $\begin{array}{l}\text { Rhabditomorpha contains many taxa with phoretic } \\
\text { relationships with arthropods and molluscs }\end{array}$ \\
\hline $\begin{array}{l}2 \text { (multiple } \\
\text { events) }\end{array}$ & $\begin{array}{l}\text { Diplogasteromorpha (e.g. } \\
\text { Parasitodiplogaster, Medhinema, } \\
\text { Cephalobium) }\end{array}$ & & Directly transmitted parasite & $\begin{array}{l}\text { Diplogasteromorpha contains many species with phoretic or } \\
\text { necromenic associations with arthropods }\end{array}$ \\
\hline 3 & Drilonematomorpha & Clitellata & Directly transmitted parasite & \\
\hline 4 & Steinernematidae, Allantonematidae & Hexapoda & Directly transmitted parasite & $\begin{array}{l}\text { Some species show 'alternation of generations' where the } \\
\text { parasite can reproduce both within and outside the host }\end{array}$ \\
\hline $\begin{array}{l}5 \text { (multiple } \\
\text { events) }\end{array}$ & $\begin{array}{l}\text { Hexatylina, Aphelenchoidea, } \\
\text { Sphaerularoidea (and others) }\end{array}$ & Hexapods & Castrator, Directly transmitted parasite & $\begin{array}{l}\text { Daubaylia, a parasite of snails, may be a member of } \\
\text { Tylenchomorpha }\end{array}$ \\
\hline 6 & Rhigonematiomorpha & Myriapoda & Directly transmitted parasite & $\begin{array}{l}\text { Rhigonematomorpha is nested within the otherwise vertebrate } \\
\text { parasitic Spirurina; the group contains no vertebrate } \\
\text { parasites }\end{array}$ \\
\hline 7 & Oxyuridomorpha & Arthropoda & Directly transmitted parasite & $\begin{array}{l}\text { Oxyuroidomorpha is nested within the otherwise vertebrate } \\
\text { parasitic Spirurina; the group also contains vertebrate } \\
\text { parasites }\end{array}$ \\
\hline 8 & Monhysterina (Gammarinema) & Crustacea & ?Directly transmitted parasite & May be classed as 'commensals' rather than parasites \\
\hline 9 & Ironina & Annelida & ?Directly transmitted parasite & \\
\hline 10 & Mermithida & Arthropoda & Parasitoid & \\
\hline \multicolumn{5}{|c|}{ Vertebrate hosts } \\
\hline 1 & Strongyloidea & Vertebrates & $\begin{array}{l}\text { Directly transmitted parasite, Trophically } \\
\text { transmitted parasite, Vector transmitted } \\
\text { parasite }\end{array}$ & $\begin{array}{l}\text { Some species have non-vertebrate paratenic or vector hosts; } \\
\text { Heterorhabditis is a sister group to the vertebrate parasites }\end{array}$ \\
\hline $\begin{array}{l}2 \text { (multiple } \\
\text { events) }\end{array}$ & Rhabdiasidae, Pelodera strongyloides & Anuran & Directly transmitted parasite & $\begin{array}{l}\text { There may be additional independent he precise placement of } \\
\text { Rhabdiasidae awaits resolution }\end{array}$ \\
\hline 3 & Strongyloididae & Mammals & Directly transmitted parasite & $\begin{array}{l}\text { 'Alternation of generations' where the parasite can reproduce } \\
\text { both within and outside the host }\end{array}$ \\
\hline 4 & Spiruromorpha & Vertebrates & $\begin{array}{l}\text { Directly transmitted parasite, vector transmitted } \\
\text { parasite, trophically transmitted parasite }\end{array}$ & $\begin{array}{l}\text { Includes the non-vertebrate parasitic oxyurids and } \\
\text { rhigonematids }\end{array}$ \\
\hline 5 & Trichinellida plus Dioctophymatida & Mammals & $\begin{array}{l}\text { Directly transmitted parasite, trophically } \\
\text { transmitted parasite }\end{array}$ & \\
\hline \multicolumn{5}{|l|}{ Plant hosts } \\
\hline $\begin{array}{l}1 \text { (?multiple } \\
\text { events) }\end{array}$ & Tylenchomorpha & $\begin{array}{l}\text { Viridiplantae (and } \\
\text { macroalgae) }\end{array}$ & Directly transmitted parasite, Micro-predator & $\begin{array}{l}\text { Plant parasitic groups are associated with fungal-feeding } \\
\text { groups, and there may be an association; plant parasitism }\end{array}$ \\
\hline & Diptherophorina (Trichodoridae) & Viridiplantae & Directly transmitted parasite, Micro-predator & may have arisen multiple times \\
\hline $\begin{array}{l}3 \text { (?multiple } \\
\text { events) }\end{array}$ & $\begin{array}{l}\text { Dorylaimida (Xiphinema, Longidorus } \\
\text { and others) }\end{array}$ & Viridiplantae & Directly transmitted parasite, Micro-predator & Plant parasitism may have arisen multiple times \\
\hline
\end{tabular}

a There are many isolated additional descriptions of nematode associations with other taxa.

b The numbering of events follows Fig. 1 .

c See Poulin (2011); Poulin and Randhawa (2013) for details. 
(particularly in Rhabditomorpha). It has been suggested that adaptation to rich food sources low in available oxygen such as rotting vegetation might predispose some groups to the acquisition of parasitic habits as the guts of other animals might offer a similar set of environmental challenges.

Echoes of the 'great chain of being', a world view common since pre-Darwinian times but still expressed today, can be heard in many discussions of parasite evolution. Parasites are suggested to be likely to show regression, losing morphological and metabolic complexity as they come to rely on hosts for more and more of the details of life as a metazoan. However, while a gut parasite might rely on the host for metabolic provisioning (thus implying a scope for simplification), it may also be subject to new stresses and demands in terms of countering host immunity (implying evolution of novelty). Similarly, parasites that utilize multiple hosts, or have major transitions in lifestyle, might be expected to gain or at least retain metabolic complexity, as they require toolkits to thrive in several distinct environments. Morphological novelties are common in parasitic nematodes: buccal teeth in hookworms (Chromadoria; Strongylomorpha); tagmatization in Trichuris (Dorylaimia; Trichinellidae); ornate spines, flanges and other cuticular decorations observed in arthropodparasitic Oxyuridomorpha and Rhigonematomorpha (Chromadoria; Spirurina).

Even parasites with apparently simple life cycles can have very complex biology. Most Ascaridids infect new hosts through ingestion of embryonated eggs from the environment, and are often used as examples of simple, direct life cycles. Ascaris suum, which enters the host intestine as larvae arrested within a protective eggshell, but then invades the gut wall, enters the bloodstream, and reinfects the gut by exiting from the capillaries in the lungs, climbing the tracheal tree and returning to the gut by being swallowed, has a very complex in-host life cycle. This migration seems against reason, as it is costly to the parasite, and has been argued to be retention of an ancient trait of migration derived from a vector-borne ancestor. Retention of a costly phenotype in contemporary species requires explanation. The answer, derived by analysis of species pairs that differ in whether they migrate or not, is simply that migration is strongly associated with adult body size and with adult fecundity: migration is an adaptive trait maintained by selection (Skorping et al. 1991; Read and Skorping, $1995 a, b$ ). It may be that the ability to migrate was inherited from an ancestral species, but its presence in living taxa is because it is currently adaptive.

\section{GENOMICS AND PARASITISM}

The first metazoan genome to be sequenced was that of a nematode: C. elegans (Chromadoria; Rhabditomorpha)
(The C. elegans Genome Sequencing Consortium 1998) and nematode parasitologists were early adopters of the genomics toolkit (Blaxter et al. 1996, 1997). A major effort over the past 20 years has delivered a large body of data on the transcribed genes of nematodes, initially through Sanger dideoxy sequencing expressed sequence tag sampling approaches (Parkinson et al. 2004) but latterly using the new sequencing technologies to deliver whole transcriptomes (Blaxter et al. 2012). The roster of nematode species with significant transcriptome data publicly available now exceeds 100 . These data have been critical in revealing genes associated with parasitic traits, and in identifying new drug targets and vaccine candidates (Elsworth et al. 2011).

The first parasitic nematode genome to be sequenced was that of Brugia malayi (Chromadoria; Spiruromorpha) (Ghedin et al. 2007). To date 19 nematode genome sequences have been published (see Fig. 1A and Table 2), and the majority of these genomes derive from parasites. As might be expected there is a bias in the species chosen for sequencing, and vertebrate and especially human parasites are over-represented. New sequencing technologies allow a new draft genome to be generated with very little resource, and more and more groups are now exploring the genomes of their target taxa. A loose alliance of nematode genome-interested biologists has been founded, and is nucleating the sequencing of as many genomes across the diversity of the phylum as is possible. The 959 Nematode Genomes initiative (Kumar et al. 2012a,b) mimics other community genome programmes such as the insect $5 \mathrm{k}$ project (i5K Consortium, 2013) (excepting that the headline goal is derived from the number of somatic cells in the adult female hermaphrodite $C$. elegans). It allows contributors to post information on the genomes they are pursuing and update the community as to their successes, and is a clearing-house for queries and collaborations (see http://www. nematodegenomes.org). By showing that genome sequencing, assembly, annotation and interpretation are within the reach of any research community, the initiative now has recorded well over 100 species for which genome data have been or are being generated.

We have been working to deliver genomic data for a number of species of key interest. These include free-living species (for example representatives of the under-sampled Enoplia, and additional Caenorhabditis species that will illuminate the biology of the model C. elegans) as well as parasites (Table 2). Using shortread next-generation sequencing technologies, and freely available assembly and annotation toolkits, we have been able to deliver important new genomes to the research communities. While generation of genomes of the quality and completeness of C. elegans would still require very significant 
Table 2. Nematode genome sequences

\begin{tabular}{|c|c|c|c|c|c|c|}
\hline Species & Systematic position & $\begin{array}{l}\text { Genome } \\
\text { size }(\mathrm{Mb})^{\mathrm{a}}\end{array}$ & $\begin{array}{l}\text { Contiguity of } \\
\text { assembly N50 } \\
(\mathrm{kb})\end{array}$ & $\begin{array}{l}\text { Number of } \\
\text { scaffolds }\end{array}$ & $\begin{array}{l}\text { Number of nuclear } \\
\text { protein-coding genes } \\
\text { predicted }\end{array}$ & Web link for access (publication) \\
\hline \multicolumn{7}{|l|}{ Clade I: Dorylaimia } \\
\hline Romanomermis culicivorax & Mermithida & $322 \cdot 77$ & 17632 & 62537 & 10206 & http://romanomermis.nematod.es (Schiffer et al. 2013) \\
\hline Trichinella spiralis & Trichinellida & $63 \cdot 51$ & 6373445 & 6819 & 16380 & $\begin{array}{l}\text { www.wormbase.org/species/t_spiralis (Mitreva } \text { et al. } \\
\text { 2011) }\end{array}$ \\
\hline \multicolumn{7}{|l|}{ Clade III: Spirurina } \\
\hline Acanthocheilonema viteae & Spiruromorpha & $77 \cdot 35$ & 25808 & 6796 & 10397 & $\begin{array}{l}\text { http://acanthocheilonema.nematod.es } \\
\text { http://badger.bio.ed.ac.uk/filarial/ }\end{array}$ \\
\hline Ascaris suum & Ascaridomorpha & $334^{\mathrm{c}}$ & 290558 & 260 & 15446 & http://ascaris.nematod.es (Wang et al. 2012) \\
\hline Brugia malayi & Spiruromorpha & $94 \cdot 14$ & 191089 & 9827 & 17846 & $\begin{array}{l}\text { www.wormbase.org/species/b_malayi (Ghedin et al. } \\
\text { 2007) }\end{array}$ \\
\hline $\begin{array}{l}\text { Dirofilaria immitis (and } \\
\text { Wolbachia wDi) }\end{array}$ & Spiruromorpha & $\begin{array}{l}88 \cdot 30 \\
(0 \cdot 92)\end{array}$ & $\begin{array}{l}22560 \\
(919954)\end{array}$ & $71281(2)$ & $16061(871)$ & $\begin{array}{l}\text { http://dirofilaria.nematod.es } \\
\text { http://badger.bio.ed.ac.uk/filarial/ (Godel } \text { et al. 2012) }\end{array}$ \\
\hline $\begin{array}{l}\text { Litomosoides sigmodonti (and } \\
\text { Wolbachia wLs) }\end{array}$ & Spiruromorpha & $\begin{array}{c}64 \cdot 81 \\
(1 \cdot 05)\end{array}$ & $\begin{array}{l}45863 \\
(605213)\end{array}$ & $3165(10)$ & $10246(1042)$ & $\begin{array}{l}\text { http://litomosoides.nematod.es } \\
\text { http://badger.bio.ed.ac.uk/filarial/ (Comandatore et al } \text {. } \\
\text { 2013) }\end{array}$ \\
\hline Loa loa & Spiruromorpha & $91 \cdot 37$ & 174388 & 5770 & 15444 & $\begin{array}{l}\text { www.broadinstitute.org/annotation/genome/ } \\
\text { filarial_worms (Desjardins et al. 2013) }\end{array}$ \\
\hline $\begin{array}{l}\text { Onchocerca ochengi (and } \\
\text { Wolbachia wOo) }\end{array}$ & Spiruromorpha & $\begin{array}{l}95 \cdot 51 \\
(0 \cdot 96)\end{array}$ & $\begin{array}{l}12317 \\
(957990)\end{array}$ & $24057(1)$ & $13990(664)$ & $\begin{array}{l}\text { http://onchocerca.nematod.es } \\
\text { http://badger.bio.ed.ac.uk/filarial/ (Darby et al. 2012) }\end{array}$ \\
\hline Wuchereria bancrofti & Spiruromorpha & $81 \cdot 51$ & 5161 & 25884 & 19327 & $\begin{array}{l}\text { www.broadinstitute.org/annotation/genome/ } \\
\text { filarial_worms (Desjardins et al. 2013) }\end{array}$ \\
\hline \multicolumn{7}{|l|}{ Clade IV: Tylenchina } \\
\hline Panagrellus redivivus & Panagrolaimomorpha & $65 \cdot 06$ & 267941 & 867 & 24249 & $\begin{array}{l}\text { www.wormbase.org/species/p_redivivus (Srinivasan } \\
\text { et al. 2013) }\end{array}$ \\
\hline Bursaphelenchus xylophilus & Tylenchomorpha & $74 \cdot 56$ & 949830 & 5526 & 18074 & $\begin{array}{l}\text { www.wormbase.org/species/b_xylophilus (Kikuchi } \\
\text { et al. 2011) }\end{array}$ \\
\hline Meloidogyne hapla & Tylenchomorpha & $53 \cdot 02$ & 37608 & 3452 & 14420 & $\begin{array}{l}\text { www.wormbase.org/species/m_hapla (Opperman et al. } \\
\text { 2008) }\end{array}$ \\
\hline Meloidogyne incognita & Tylenchomorpha & $82 \cdot 09$ & 12786 & 9533 & 19212 & $\begin{array}{l}\text { www.wormbase.org/species/m_incognita (Abad et al. } \\
\text { 2008) }\end{array}$ \\
\hline Meloidogyne floridensis & Tylenchomorpha & $96 \cdot 67$ & 3698 & 58696 & 11975 & http://meloidogyne.nematod.es (Lunt et al. 2014) \\
\hline \multicolumn{7}{|l|}{ Clade V: Rhabdina } \\
\hline Caenorhabditis angaria & Rhabditomorpha & $99 \cdot 01$ & 87708 & 11453 & 27967 & $\begin{array}{l}\text { www.wormbase.org/species/c_angaria (Mortazavi et al. } \\
\text { 2010) }\end{array}$ \\
\hline Caenorhabditis briggsae & Rhabditomorpha & $108 \cdot 42$ & 17485439 & 12 & 21850 & $\begin{array}{l}\text { www.wormbase.org/species/c_briggsae (Stein et al. } \\
\text { 2003) }\end{array}$ \\
\hline Caenorhabditis elegans & Rhabditomorpha & $100 \cdot 29$ & 17493829 & 7 & 20520 & $\begin{array}{l}\text { www.wormbase.org/species/c_elegans (The C. elegans } \\
\text { Genome Sequencing Consortium 1998) }\end{array}$ \\
\hline Caenorhabditis sp 1 & Rhabditomorpha & $109 \cdot 33$ & 24542 & 14350 & d & http://caenorhabditis.nematod.es \\
\hline
\end{tabular}


effort, producing an assembly that is verifiably near-complete (albeit fragmented), and a gene set that is useful for a wide range of subsequent analyses, is relatively routine. A major remaining issue is that of heterozygosity in wild-sourced specimens. The $C$. elegans genome was derived from an essentially homozygous matrilineal clone, and the $B$. malayi genome from a highly inbred stock. Wild-caught, or recently colonized, nematode species will carry high levels of heterozygosity, and several animal and plant-parasitic nematode genome projects have struggled with the issues that extreme levels of heterozygosity (even in parasite lines maintained for a long time in laboratories) bring. Thus assemblies of new species may not reach the contiguity and completeness of the model genomes because of fundamental biological issues, and technical improvements and innovations, both wet laboratory and bioinformatic, are required.

Genome complexity does not appear to be closely tied to life habit. In terms of genome sizes, while some parasites (such as Meloidogyne hapla, with an estimated genome span of $54 \mathrm{Mb}$ (Opperman et al. 2008)) have smaller genomes than those of free-living relatives (both cephalobes and rhabditids have genomes from 100-200 Mb), the largest genomes known thus far are in parasites (Romanomermis culicivorax has a genome of $\sim 322 \mathrm{Mb}$ (Schiffer et al. 2013), A. suum $334 \mathrm{Mb}$ (Wang et al. 2012) and Haemonchus contortus $370 \mathrm{Mb}$ (Laing et al. 2013)). Within clades, genome sizes can vary widely (for example within the genus Meloidogyne sizes range from $54 \mathrm{Mb}$ in M. hapla to $150 \mathrm{Mb}$ estimated in Meloidogyne incognita (Abad et al. 2008; Lunt et al. 2014)), and this is associated with polyploidy. The knowledge of genome sizes of free-living nematodes outside the Rhabditomorpha is very sparse, and it may be that free-living, diploid species' genomes regularly exceed the twofold range known thus far. In general, the numbers of genes predicted from parasitic species are less than or equivalent to those predicted from free-living species. Caenorhabditis elegans has $\sim 21800$ protein-coding genes, while $H$. contortus (Chromadoria; Strongylomorpha) has 20600 (Laing et al. 2013). However, the mermithid R. culicivorax (Dorylaimia; Mermithida) has $\sim 12000$ (Schiffer et al. 2013), Trichinella spiralis (Dorylaimia; Trichinellida) has only 15800 (Mitreva et al. 2011), and the onchocercid nematodes (B. malayi and relatives; Chromadoria; Spiruromorpha) have between 12000 and 14000 (Godel et al. 2012; Desjardins et al. 2013). Whether this reveals a loss of genic complexity in some parasites, or an overall more complex genomic heritage in the Rhabditina remains unclear. Changes in genome size are generally reflected in congruent changes in intron length, intergenic distance and repeat content. 
HORIZONTAL GENE TRANSFERS INTO NEMATODE GENOMES

Plant parasitic nematodes must overcome the formidable defences of the plant cell wall in order to extract nutrition from their hosts. In addition, many sedentary plant parasites induce galls of various forms, structures induced in the plant by a parasite that must 'know' some of the tricks of plant developmental biology. Plant parasitic species secrete cellulolytic enzymes, and cloning and sequencing of these effectors revealed that some had their closest homologues in rhizosphere fungi and bacteria rather than other animals (Smant et al. 1998). These enzymes became the first robustly supported instances of horizontal or horizontal gene transfer into nematode genomes. A diverse roster of plant cell wall-degrading enzymes is now known from cyst and root-knot nematodes (Bird et al. 2014), and supplemented by piecemeal understanding of the repertoires of other phytopathogenic species. Phylogenetic inference suggests that these horizontally transferred genes were acquired early in the evolution of the Tylenchomorpha (Danchin et al. 2010; RybarczykMydlowska et al.2012). It is likely, given the inferred species of origin of the genes, that there were several independent events of gene acquisition (Mitreva et al. 2009). Surveying tylenchomorph transcriptomes and genomes for genes with sequence-similarity profiles similar to those of the validated horizontal gene transfers reveals a wide range of candidates that include nod factor homologues and genes of unknown function that have disjunct distributions in plants and plant-parasitic nematodes, or in root bacteria and plant parasitic nematodes (Elsworth et al. 2011).

Importantly, horizontally transferred plant cell wall-degrading enzymes have also been identified in parasites from the other independently evolved plant-parasitic groups (Diptherophorina in Enoplia and Dorylaimida in Dorylaimia), suggesting that while the transition to phytophagy was difficult, it involved similar evolutionary trajectories in each case: the acquisition of the necessary toolkit from professional saprophytes in the root environment. It is interesting in this respect that similar cellulolytic enzymes have been identified in the freeliving Pristionchus pacificus and related species (Rhabditina; Diplogateromorpha) (Mayer et al. 2011). Horizontally acquired genes are evident in other species, including $C$. elegans (Parkinson and Blaxter, 2003).

The close association between animal parasites and their hosts, and the requirement to specifically modulate especially the adaptive and anamnestic immune responses of vertebrate hosts, raises the question as to whether animal parasites also acquired novel genes from their hosts, or other commensals of these hosts. Surveys of expressed sequence tag datasets from plant parasitic species identified many potential horizontal transfer candidates, but very few candidates were identified in either transcriptome data from across the diversity of animal parasites, or in the genomes of animal parasites in Strongylomorpha, Ascaridomorpha, Spiruromorpha or Trichinellida (Elsworth et al. 2011). One interesting horizontally acquired gene in the Spiruromorpha is an alphaproteobacteria-like, second copy of ferrochelatase, an enzyme involved in the synthesis of haem (Elsworth et al. 2011). This gene is present in onchocercid nematodes (B. malayi and relatives), and suggests an additional or distinct requirement for haem in these tissue and blood parasites (Wu et al. 2013). The ferrochelatase is quite distinct from that found in the Wolbachia symbionts of onchocercids (see below).

\section{BACTERIALSYMBIONTS}

The long history of the tree of life is punctuated by many, highly significant events of symbiosis. In the Nematoda, several distinct types of symbiosis with bacteria have been recorded (Murfin et al. 2012). The free-living Stilbonematidae (Chromadoria) associate specifically with gammaproteobacteria that grow as a lawn on the nematodes' cuticle. These sulphur-fixing bacteria act as a major food source for the nematode, and the nematodes 'farm' their bacterial associates by migrating to $\mathrm{H}_{2} \mathrm{~S}$-rich sediment layers (Bulgheresi 2011; Murfin et al. 2012). In Anoplostoma (Enoplia), adult nematodes have neither mouth nor anus, and their guts are filled with a sulphur-fixing symbiont. Other similar trophic symbioses undoubtedly await discovery.

The entomopathogenic genera Heterorhabditis (Rhabditina, Strongylomorpha) (Bai et al. 2013) and Steinernema (Tylenchina, Panagrolaimomorpha) (Goodrich-Blair, 2007) share a life-cycle strategy that utilizes specific Entobacteriaciae bacterial symbionts (Photorhabdus with Heterorhabditis, Xenorhabdus with Steinernema) to kill newly invaded insect larvae, and then to provide nutrition to the growing and reproducing nematodes. While the symbionts used and the details of the interactions differ, the convergence of these two nematode genera on the same general strategy is remarkable. In the plantparasitic Xiphinema (Dorylaimia; Dorylaimida), a veruccomicrobial symbiont, Xiphinematobacter, is found intracellularly (Vandekerckhove et al. 2000). Its role in the biology of the nematode is largely unknown, although the symbiont is maternally transmitted and may play a role in modification of the nematodes' reproductive mode.

The alphaproteobacterium Wolbachia pipientis was first described from insects, where they are reproductive parasites, manipulating the reproductive status, gender or sexual compatibility of their hosts (O’Neill, 1995; Werren, 1997). Wolbachia have subsequently been found in a range of terrestrial 
arthropods, and from nematodes. Molecular phylogenetic data suggest the presence of supergroups of Wolbachia that have distinct biology and host distributions (Lo et al. 2002). Supergroup A and B Wolbachia are most widespread, and are found in insects. Nematodes are infected with supergroup C, $\mathrm{D}$ and $\mathrm{F}$ Wolbachia. Wolbachia have been described from the Spiruromorpha (in the Onchocercidae), and the Tylenchomorpha (Radopholus similis is the only species with infection described to date) (Jacob et al. 2008; Haegeman et al. 2009). General surveys using Wolbachia-specific PCR assays of many other nematode species have been negative (Bordenstein et al. 2003; Duron and Gavotte, 2007; Foster et al. 2008). However, in $R$. similis (Tylenchina, Tylenchomorpha) the identification of expressed sequence tags corresponding to likely Wolbachia genes led to the identification of an intracellular symbiont in this plant parasite (Jacob et al. 2008; Haegeman et al. 2009).

In supergroups $\mathrm{A}$ and $\mathrm{B}$, the symbiont phylogeny does not match that of its hosts, and host species tend to include both infected and uninfected individuals, reflecting frequent loss and acquisition of the symbiont through phylogenetic time. This pattern reflects the parasitic nature of the symbiosis. In contrast, supergroup C and D Wolbachia from onchocercid nematodes show traits suggestive of long, and possibly essential, mutualist interactions. The Wolbachia and nematode host phylogenies are congruent, indicating little if any host switching (Bandi et al. 1998; Casiraghi et al. 2004). In infected species, all individuals are infected, and killing of the Wolbachia with antibiotics such as tetracyclines also affects the viability of the nematode host, with loss of fecundity and nematode death (Bandi et al. 1999; Hoerauf et al. 1999; Landmann et al. 2011, 2012). The exact nature of the mutualism remains unclear: the Wolbachia may assist the nematode metabolically (the distribution of bacteria in adult nematodes is reminiscent of the distribution of essential nutritive Buchnera bacteria in aphids) or in evading the vertebrate host's immune system (by confusing T-helper cell polarization with bacterial and metazoan signals at the same time) (Fenn and Blaxter, 2004, 2007; Darby et al. 2012). Genome sequencing of filarial Wolbachia has permitted culling of the possible hypotheses for essentiality, but has not yielded data that definitively support specific metabolic $v s$ immunoprotective roles (Darby et al. 2012). It is also possible that the interference of the Wolbachia with oogenesis and development (Landmann et al. 2011, 2012) makes it difficult, in evolutionary terms, for the nematode to rid itself of the symbionts. The symbiosis is not essential in the phylogenetic long term, as there are onchocercid species, such as Loa loa, Onchocerca flexuosa and Acanthocheilonema viteae, which have lost the infection and are now Wolbachia-free. Genomically, filarial Wolbachia display the expected phenotypes of mutualist endosymbionts: the genomes are reduced compared with the insect-parasitic supergroups $\mathrm{A}$ and $\mathrm{B}$, with fewer protein coding genes and a lack of mobile elements such as phage (Comandatore et al. 2013).

The onchocercid nematodes that lack living Wolbachia still retain a signature of past infection in the form of horizontally transferred fragments of Wolbachia-like DNA in their nuclear genomes (McNulty et al. 2013). Species that have live Wolbachia also have horizontally transferred Wolbachia-like fragments in their genomes (Dunning-Hotopp et al. 2007; Ioannidis et al. 2013). Horizontal transfer of organellar DNA to the nucleus is common, and thus the presence of these Wolbachia fragments could simply be a product of non-functional, stochastic incorporation of Wolbachia fragments into the genome (Blaxter, 2007). More excitingly, these inserted fragments could be being used by the nuclear genome to express new, Wolbachia-derived proteins. While some Wolbachia fragments are expressed at low levels (Ioannidis et al. 2013), most are not, and most are gene fragments that also have disabling mutations that render them inactive. Comparisons between the nuclear genomes of onchocercid species with and without Wolbachia has identified few shared insertions and no smoking gun of a constrained, conserved transfer that might substitute for a live Wolbachia.

The other Wolbachia found in nematodes are much less well-studied. Some onchocercid nematodes carry a Wolbachia that is placed in supergroup $\mathrm{F}$, alongside Wolbachia from termites, fleas and bedbugs (Bordenstein et al. 2003; Duron and Gavotte, 2007; Foster et al. 2008; Jacob et al. 2008; Haegeman et al. 2009; Comandatore et al. 2013). Initial analyses suggested that the $R$. similis Wolbachia was distantly related to any other supergroup (Jacob et al. 2008; Haegeman et al. 2009), but this result is questionable (Koutsovoulos et al. 2014). The bovine lungworm Dictyocaulus viviparus (Rhabditina, Strongylomorpha) was not known to have any association with Wolbachia until its genome was sequenced (Koutsovoulos et al. 2014). Within the nuclear genome contigs were $\sim 1 \mathrm{Mb}$ of DNA fragments that had highest similarity to Wolbachia genomes (Koutsovoulos et al. 2014). These fragments bore all the hallmarks of being non-functional horizontal transfers from a once-present Wolbachia. Using these horizontally transferred fragments, the likely source of the transfer was identified as a supergroup $\mathrm{F}$ Wolbachia. The D. viviparus data allow resolution of the relationship of supergroup F (and the Wolbachia from $R$. similis) as sisters to supergroups $\mathrm{C}$ and D. The fragments in the $D$. viviparus genome included remnants of bacteriophage, suggesting that the source genome might have been more like that of the parasites of supergroup A and B than the reduced $\mathrm{C}$ and $\mathrm{D}$ symbionts. It will be important to survey 
other emerging nematode genomes for evidence of past association with Wolbachia, and perhaps other bacteria, and thus reveal the extent of the interactions between these symbionts and nematodes, and perhaps even identify particular associations with parasitism.

\section{A GENOME-BASED TREE OF NEMATODA}

One critical issue that molecular phylogenetic analyses now face is that more data are needed. To date, most analyses have used a single locus, the nuclear small subunit ribosomal RNA gene (nSSU). The $\mathrm{nSSU}$ is a good gene for deep phylogenetics, but the phylogenetic history that can be extracted from its $\sim 1800$ bases is limited. There are now over 8000 nematode nSSU sequences in the public sequence databases (many fragmentary) from over 4000 nominal species. It is not possible to derive a robustly supported tree from this many sequences, and many internal nodes that were unresolved in the earliest analyses remain unresolved in the most recent ones (Holterman et al. 2006; van Megen et al. 2009; Bik et al. 2010), probably because of a lack of unambiguous signal in the single, short nSSU locus. The mitochondrial genome is a readily accessed source of data for phylogenetic inference, and complete genomes are available for over 40 species. These have yielded phylogenies that are well-resolved but at odds with nSSU phylogenies (Park et al. 2011; Sultana et al. 2013). Specifically, neither Spiruria (Blaxter et al. 1998) nor Tylenchina are recovered as monophyletic, and the sister relationship between Heterorhabditis bacteriophora and Strongylomorpha is not recovered (Park et al. 2011; Sultana et al. 2013). Whether these differences arise from biases or errors in the nuclear or mitochondrial data that have not been mitigated remains to be clarified.

One key utility of the new genome-wide data from a wide range of nematode species is that we have a much larger set of data to draw on when compiling matrices for phylogenetic inference (Jones et al. 2011). A major issue is the selection of loci that are orthologous (i.e. where representatives in different species have their origin in a single instance in an ancestral species) and where data coverage is relatively complete. Using gene sets inferred from complete genome sequences, and also complete or high-density transcriptome data, it is possible to infer a set of orthologous genes across the breadth of the phylum. One approach to achieving this is to use a tool such as Core Eukaryotic Genes Mapping Approach (CEGMA) (Parra et al. 2007), which identifies a set of 248 genes known to be present in six model eukaryote species. These genes tend to be highly conserved in sequence, and one limitation resulting from their use may be that there is not enough variation to record closely spaced, or recent branching patterns. An alternative approach is to generate a sequence-based clustering of all genes from all the species under study, using a tool such as orthoMCL (Li et al. 2003), and to query the resultant data for putative sets of orthologues. Using these approaches it is possible to build datasets that include many hundreds of thousands of aligned nucleotides (and several hundred thousand aligned codons or amino acids). These datasets can then be used to address questions left unanswered by the nSSU datasets. First attempts to explore resolution of the deeper phylogeny of Nematoda with multiple nuclear genes derived from whole-genome sequencing priojects have largely supported the existing nSSUderived phylogeny, albeit with limited taxon representation (Desjardins et al. 2013; Laing et al. 2013).

The true power of this phylogenomic approach will only be realized when many hundred nematode genomes representing known diversity are sequenced, but already large datasets can be collated and explored. We have used a combination of wholegenome-derived and transcriptomics-derived gene sets to, firstly, attempt to replicate the findings from the nSSU analyses performed previously, and secondly to resolve some of the remaining unresolved polytomies and conflicts between analyses (Fig. 1B) (Blaxter et al. 2014). Analyses were performed with data from 181 genes from 23 nematode taxa including representatives of the Dorylaimia, Enoplia and Chromadoria. Taxon sampling remained most limited in Enoplia (a single representative, Enoplus brevis), and in the comb-like series of ordinal taxa subtending the Rhabditida in Chromadoria (only Laxus oneistus from Chromadorida). With these taxa the major clades $(\mathrm{I}-\mathrm{V})$ that were identified using nSSU (Blaxter et al. 1998) were recovered, the branching order of clades III (Spirurina), IV (Tylenchina) and $\mathrm{V}$ (Rhabditina) was resolved as (III, $(\mathrm{IV}, \mathrm{V})$ ), and the Enoplia were robustly resolved as arising basal to Dorylaimia plus Chromadoria. While $E$. brevis has a relatively short branch length in these analyses, we caution that its placement may be artefactual due to phylogenetic artefacts elsewhere in the tree, or outgroup problems.

\section{PROSPECTS}

The 959 Nematode Genomes initiative notes nearly 100 genomes in progress for the phylum. We have heard anecdotally of many more taxa where researchers are approaching their research goals through genome sequencing, or deep transcriptome sequencing. Improved sequencing technologies such as long single-molecule reads will improve the contiguity of genomes, and improved algorithms will enable assembly even in the presence of high levels of heterozygosity. Careful sampling, and methods for unbiased amplification of genomic DNA from single specimens will fill in the diversity of the tree, and multi-locus phylogenies provide deep resolution 
of relationships. The next few years will also see the development of rich collated resources for nematode genomes, including shared genome browsing environments, robust inferences of gene orthology and gene family evolution, and identification of genes and gene families that show particular patterns of evolution associated with distinct clades in the phylum. In addition, with the development of robust protocols for RNA-based interference in many species, and the development of specific genome editing methods that can be applied to any organism, we expect that questions of the specific roles of many genes to be elucidated. As ever, the questions remain biological: which traits and which genomic features are associated with parasitism, what selective forces maintain them, and how do these change through the ongoing struggle between host and parasite?

\section{ACKNOWLEDGEMENTS}

We thank our colleagues in Edinburgh and elsewhere who have been working with us on sequencing, assembly and annotation of nematode genomes, in particular Sujai Kumar. We thank Andrew Jackson, Matt Berriman and James Cotton for inviting MB to participate in the Wellcome Trust workshop on 'The evolution of parasite genomes and the origins of parasitism'. We apologize to colleagues whose work we were unable to reference due to limitations of space.

\section{REFERENCES}

Abad, P., Gouzy, J., Aury, J. M., Castagnone-Sereno, P., Danchin, E. G., Deleury, E., Perfus-Barbeoch, L., Anthouard, V., Artiguenave, F., Blok, V.C., Caillaud, M. C., Coutinho, P. M., Dasilva, C., De Luca, F., Deau, F., Esquibet, M., Flutre, T., Goldstone, J. V., Hamamouch, N., Hewezi, T., Jaillon, O., Jubin, C., Leonetti, P., Magliano, M., Maier, T. R., Markov, G. V., McVeigh, P., Pesole, G., Poulain, J., Robinson-Rechavi, M., Sallet, E., Segurens, B., Steinbach, D., Tytgat, T., Ugarte, E., van Ghelder, C., Veronico, P., Baum, T. J., Blaxter, M., Bleve-Zacheo, T., Davis, E. L., Ewbank, J. J., Favery, B., Grenier, E., Henrissat, B., Jones, J.T., Laudet, V., Maule, A. G., Quesneville, H., Rosso, M. N., Schiex, T., Smant, G., Weissenbach, J. and Wincker, P. (2008). Genome sequence of the metazoan plant-parasitic nematode Meloidogyne incognita. Nature Biotechnology 26, 882-884.

Aguinaldo, A. M. A., Turbeville, J. M., Linford, L. S., Rivera, M. C., Garey, J. R., Raff, R. A. and Lake, J. A. (1997). Evidence for a clade of nematodes, arthropods and other moulting animals. Nature 387, 489-493. Bai, X., Adams, B. J., Ciche, T. A., Clifton, S., Gaugler, R., Kim, K. S., Spieth, J., Sternberg, P. W., Wilson, R. K. and Grewal, P. S. (2013). A lover and a fighter: the genome sequence of an entomopathogenic nematode Heterorhabditis bacteriophora. PLOS ONE 8, e69618. doi: 10.1371/journal. pone. 0069618

Bandi, C., Anderson, T. J., Genchi, C. and Blaxter, M. L. (1998). Phylogeny of Wolbachia in filarial nematodes. Proceedings of the Royal Society: Biological Science 265, 2407-2413.

Bandi, C., McCall, J.W., Genchi, C., Corona, S., Venco, L. and Sacchi, L. (1999). Effects of tetracycline on the filarial worms Brugia pahangi and Dirofilaria immitis and their bacterial endosymbionts Wolbachia. International Fournal for Parasitology 29, 357-364.

Bik, H. M., Lambshead, P. J., Thomas, W. K. and Lunt, D. H. (2010). Moving towards a complete molecular framework of the Nematoda: a focus on the Enoplida and early-branching clades. BMC Evolutionary Biology 10, 353. doi: 10.1186/1471-2148-10-353.

Bird, D. M., Jones, J.T., Opperman, C. H., Kikuchi, T. and Danchin, E. G. J. (2014). Signatures of adaptation to plant parasitism in nematode genomes. Parasitology. doi: 10.1017/S0031182013002163.

Blaxter, M. (2007). Symbiont genes in host genomes: fragments with a future? Cell Host and Microbe 2, 211-213.
Blaxter, M. and Denver, D. R. (2012). The worm in the world and the world in the worm. BMC Biology 10, 57. doi: 10.1186/1741-7007-10-57. Blaxter, M., Kumar, S., Kaur, G., Koutsovoulos, G. and Elsworth, B. (2012). Genomics and transcriptomics across the diversity of the Nematoda. Parasite Immunology 34, 108-120. doi: 10.1111/j.1365-3024. 2011.01342.x.

Blaxter, M., Koutsovoulos, G., Jones, M., Kumar, S. and Elsworth, B. (2014). Phylogenomics of Nematoda. In Next-Generation Systematics (ed. Cotton, J., Hughes, J. and Olson, P.). Cambridge University Press, Cambridge, UK.

Blaxter, M. L., Raghavan, N., Ghosh, I., Guiliano, D., Lu, W., Williams, S. A., Slatko, B. and Scott, A. L. (1996). Genes expressed in Brugia malayi infective third stage larvae. Molecular and Biochemical Parasitology 77, 77-96.

Blaxter, M. L., Daub, J., Waterfall, M., Guiliano, D., Williams, S., Jayaraman, K., Ramzy, R., Slatko, B. and Scott, A. (1997). The Filarial Genome Project. In Genetic and Molecular Biology of Entomopathogenetic Nematodes (ed. Abad, P., Burnell, A., Laumond, C., Boemare, N. and Coudert, F.), pp. 47-58. The Commission of the European Community, Brussels, Belgium

Blaxter, M. L., De Ley, P., Garey, J. R., Liu, L.X., Scheldeman, P., Vierstraete, A., Vanfleteren, J. R., Mackey, L.Y., Dorris, M., Frisse, L. M., Vida, J. T. and Thomas, W. K. (1998). A molecular evolutionary framework for the phylum Nematoda. Nature 392, 71-75.

Bordenstein, S. R., Fitch, D. H. A. and Werren, J. H. (2003). Absence of Wolbachia in nonfilariid nematodes. Fournal of Nematology 35, 266-270.

Bovien, P. (1937). Some Types of Association between Nematodes and Insects. Bianco Luno A/S, KBHVN, Copenhagen, Denmark.

Bulgheresi, S. (2011). Calling the roll on Laxus oneistus immune defense molecules. Symbiosis 55, 127-135. doi: 10.1007/s13199-012-0157-3.

Casiraghi, M., Bain, O., Guerrero, R., Martin, C., Pocacqua, V., Gardner, S. L., Franceschi, A. and Bandi, C. (2004). Mapping the presence of Wolbachia pipientis on the phylogeny of filarial nematodes: evidence for symbiont loss during evolution. International fournal for Parasitology 34, 191-203. doi: 10.1016/j.ijpara.2003.10.004.

Comandatore, F., Sassera, D., Montagna, M., Kumar, S., Koutsovoulos, G., Thomas, G., Repton, C., Babayan, S. A., Gray, N., Cordaux, R., Darby, A., Makepeace, B. and Blaxter, M. (2013). Phylogenomics and analysis of shared genes suggest a single transition to mutualism in Wolbachia of nematodes. Genome Biology and Evolution $\mathbf{5}$, 1668-1674. doi: $10.1093 /$ gbe/evt125.

Danchin, E. G., Rosso, M.N., Vieira, P., de Almeida-Engler, J., Coutinho, P. M., Henrissat, B. and Abad, P. (2010). Multiple lateral gene transfers and duplications have promoted plant parasitism ability in nematodes. Proceedings of the National Academy of Sciences USA 107, 17651-17656. doi: 10.1073/pnas.1008486107.

Darby, A. C., Armstrong, S. D., Bah, G. S., Kaur, G., Hughes, M. A., Kay, S. M., Koldkjaer, P., Rainbow, L., Radford, A. D., Blaxter, M. L., Tanya, V. N., Trees, A. J., Cordaux, R., Wastling, J.M. and Makepeace, B. L. (2012). Analysis of gene expression from the Wolbachia genome of a filarial nematode supports both metabolic and defensive roles within the symbiosis. Genome Research 22, 2467-2477. doi: 10.1101/gr.138420.112.

De Ley, P. and Blaxter, M. (2004). A new system for Nematoda: combining morphological characters with molecular trees, and translating clades into ranks and taxa. In Nematology Monographs and Perspectives, Vol. 2 (ed. Cook, R. and Hunt, D. J.), pp. 633-653. E.J. Brill, Leiden, the Netherlands.

De Ley, P. and Blaxter, M. L. (2002). Systematic position and phylogeny. In The Biology of Nematodes (ed. Lee, D.), pp. 1-30. Taylor \& Francis, London, UK.

Desjardins, C. A., Cerqueira, G.C., Goldberg, J. M., Dunning Hotopp, J. C., Haas, B. J., Zucker, J., Ribeiro, J. M., Saif, S., Levin, J. Z., Fan, L., Zeng, Q., Russ, C., Wortman, J. R., Fink, D. L., Birren, B.W. and Nutman, T. B. (2013). Genomics of Loa loa, a Wolbachia-free filarial parasite of humans. Nature Genetics 45, 495-500. doi: $10.1038 /$ ng. 2585 .

Dieterich, C., Clifton, S. W., Schuster, L. N., Chinwalla, A. Delehaunty, K., Dinkelacker, I., Fulton, L., Fulton, R., Godfrey, J., Minx, P., Mitreva, M., Roeseler, W., Tian, H., Witte, H., Yang, S. P., Wilson, R. K. and Sommer, R. J. (2008). The Pristionchus pacificus genome provides a unique perspective on nematode lifestyle and parasitism. Nature Genetics 40,1193-1198. doi: 10.1038/ng.227.

Dobson, A., Lafferty, K. D., Kuris, A. M., Hechinger, R.F. and Jetz, W. (2008). Colloquium paper: homage to Linnaeus: how many parasites? How many hosts? Proceedings of the National Academy of Sciences USA 105(Suppl. 1), 11482-11489. doi: 10.1073/pnas. 0803232105 
Dorris, M., De Ley, P. and Blaxter, M. L. (1999). Molecular analysis of nematode diversity and the evolution of parasitism. Parasitology Today 15, 188-193.

Dunn, C. W., Hejnol, A., Matus, D. Q., Pang, K., Browne, W. E., Smith, S. A., Seaver, E., Rouse, G. W., Obst, M., Edgecombe, G. D. Sorensen, M. V., Haddock, S. H., Schmidt-Rhaesa, A., Okusu, A., Kristensen, R. M., Wheeler, W. C., Martindale, M. Q. and Giribet, G. (2008). Broad phylogenomic sampling improves resolution of the animal tree of life. Nature 452, 745-749. doi: 10.1038/nature06614.

Dunning-Hotopp, J. C., Clark, M.E., Oliveira, D. C., Foster, J. M. Fischer, P., Munoz Torres, M. C., Giebel, J. D., Kumar, N., Ishmael, N., Wang, S., Ingram, J., Nene, R. V., Shepard, J., Tomkins, J., Richards, S., Spiro, D. J., Ghedin, E., Slatko, B. E. Tettelin, H. and Werren, J.H. (2007). Widespread lateral gene transfer from intracellular bacteria to multicellular eukaryotes. Science 317, 1753-1756. doi: 10.1126/science. 1142490 .

Duron, O. and Gavotte, L. (2007). Absence of Wolbachia in nonfilariid worms parasitizing arthropods. Current Microbiology 55, 193-197. doi: 10.1007/s00284-006-0578-4.

Elsworth, B., Wasmuth, J. and Blaxter, M. (2011). NEMBASE4: the nematode transcriptome resource. International fournal for Parasitology 41, 881-894. doi: 10.1016/j.ijpara.2011.03.009.

Fenn, K. and Blaxter, M. (2004). Are filarial nematode Wolbachia obligate mutualist symbionts? Trends in Ecology and Evolution 19, 163-166.

Fenn, K. and Blaxter, M. (2007). Coexist, cooperate and thrive: Wolbachia as long-term symbionts of filarial nematodes. Issues in Infectious Disease 5, 66-76.

Foster, J. M., Kumar, S., Ford, L., Johnston, K. L., Ben, R., Graeff-Teixeira, C. and Taylor, M. J. (2008). Absence of Wolbachia endobacteria in the non-filariid nematodes Angiostrongylus cantonensis and A. costaricensis. Parasitology Vectors 1, 31. doi: 10.1186/1756-3305-1-31. Ghedin, E., Wang, S., Spiro, D., Caler, E., Zhao, Q., Crabtree, J. Allen, J. E., Delcher, A. L., Guiliano, D. B., Miranda-Saavedra, D. Angiuoli, S. V., Creasy, T., Amedeo, P., Haas, B., El-Sayed, N. M., Wortman, J. R., Feldblyum, T., Tallon, L., Schatz, M., Shumway, M., Koo, H., Salzberg, S. L., Schobel, S., Pertea, M., Pop, M., White, O. Barton, G. J., Carlow, C. K., Crawford, M. J., Daub, J., Dimmic, M. W. Estes, C. F., Foster, J. M., Ganatra, M., Gregory, W. F., Johnson, N. M., Jin, J., Komuniecki, R., Korf, I., Kumar, S., Laney, S., Li, B. W., Li, W., Lindblom, T. H., Lustigman, S., Ma, D., Maina, C. V., Martin, D. M. McCarter, J.P., McReynolds, L., Mitreva, M., Nutman, T. B., Parkinson, J., Peregrin-Alvarez, J.M., Poole, C., Ren, Q., Saunders, L., Sluder, A. E., Smith, K., Stanke, M., Unnasch, T. R., Ware, J., Wei, A.D., Weil, G., Williams, D. J., Zhang, Y. Williams, S. A., Fraser-Liggett, C., Slatko, B., Blaxter, M. L. and Scott, A. L. (2007). Draft genome of the filarial nematode parasite Brugia malayi. Science 317, 1756-1760. doi: 10.1126/science.1145406.

Godel, C., Kumar, S., Koutsovoulos, G., Ludin, P., Nilsson, D. Comandatore, F., Wrobel, N., Thompson, M., Schmid, C. D., Goto, S. Bringaud, F., Wolstenholme, A., Bandi, C., Epe, C., Kaminsky, R., Blaxter, M. and Maser, P. (2012). The genome of the heartworm, Dirofilaria immitis, reveals drug and vaccine targets. Faseb fournal 26, 46504661. doi: 10.1096/fj.12-205096.

Goodrich-Blair, H. (2007). They've got a ticket to ride: Xenorhabdu nematophila-Steinernema carpocapsae symbiosis. Current Opinion in Microbiology 10, 225-230. doi: 10.1016/j.mib.2007.05.006.

Haegeman, A., Vanholme, B., Jacob, J., Vandekerckhove, T. T. Claeys, M., Borgonie, G. and Gheysen, G. (2009). An endosymbiotic bacterium in a plant-parasitic nematode: member of a new Wolbachia supergroup. International Fournal for Parasitology 39, 1045-1054. doi: 10.1016/j.ijpara.2009.01.006

Hallan, J. (2007). Biology Catalog: Synopsis of The Described Nematoda of The World. http://insects.tamu.edu/research/collection/hallan/Nematoda/ Hanelt, B. and Janovy, J., Jr. (1999). The life cycle of a horsehair worm, Gordius robustus (Nematomorpha: Gordioidea). Fournal of Parasitology $\mathbf{8 5}$ 139-141.

Hoerauf, A., Nissen-Pahle, K., Schmetz, C., Henkle-Duhrsen, K. Blaxter, M. L., Buttner, D. W., Gallin, M.Y., Al-Qaoud, K. M. Lucius, R. and Fleischer, B. (1999). Tetracycline therapy targets intracellular bacteria in the filarial nematode Litomosoides sigmodontis and results in filarial infertility. Fournal of Clinical Investigation 103, 11-18.

Holterman, M., van der Wurff, A., van den Elsen, S., van Megen, H., Bongers, T., Holovachov, O., Bakker, J. and Helder, J. (2006). Phylumwide analysis of SSU rDNA reveals deep phylogenetic relationships among nematodes and accelerated evolution toward crown Clades. Molecular Biology and Evolution 23, 1792-1800.

Holterman, M., Karssen, G., van den Elsen, S., van Megen, H., Bakker, J. and Helder, J. (2009). Small subunit rDNA-based phylogeny of the Tylenchida sheds light on relationships among some high-impact plantparasitic nematodes and the evolution of plant feeding. Phytopathology 99, 227-235. doi: 10.1094/PHYTO-99-3-0227.

Hunt, D. J. (1996). A synopsis of the Rhigonematidae (Nematoda), with an outline classification of the Rhigonematida. Afro-Asian Fournal of Nematology 6, 137-150.

i5K Consortium (2013). The i5 K Initiative: advancing arthropod genomics for knowledge, human health, agriculture, and the environment. Fournal of Heredity 104, 595-600. doi: 10.1093/jhered/est050.

Ioannidis, P., Johnston, K. L., Riley, D. R., Kumar, N., White, J. R., Olarte, K. T., Ott, S., Tallon, L. J., Foster, J. M., Taylor, M. J. and Dunning Hotopp, J. C. (2013). Extensively duplicated and transcriptionally active recent lateral gene transfer from a bacterial Wolbachia endosymbiont to its host filarial nematode Brugia malayi. BMC Genomics 14, 639. doi: 10.1186/1471-2164-14-639.

Jacob, J., Mitreva, M., Vanholme, B. and Gheysen, G. (2008). Exploring the transcriptome of the burrowing nematode Radopholus similis. Molecular Genetics and Genomics 280, 1-17. doi: 10.1007/s00438008-0340-7.

Jones, M. O., Koutsovoulos, G. D. and Blaxter, M. L. (2011). iPhy: an integrated phylogenetic workbench for supermatrix analyses. $B M C$ Bioinformatics 12, 30. doi: 10.1186/1471-2105-12-30.

Kampfer, S., Sturmbauer, C. and Ott, C. J. (1998). Phylogenetic analysis of rDNA sequences from adenophorean nematodes and implications for the Adenophorea-Secernetea controversy. Invertebrate Biology 117, 29-36.

Kikuchi, T., Cotton, J. A., Dalzell, J. J., Hasegawa, K., Kanzaki, N., McVeigh, P., Takanashi, T., Tsai, I. J., Assefa, S. A., Cock, P. J., Otto, T. D., Hunt, M., Reid, A. J., Sanchez-Flores, A., Tsuchihara, K., Yokoi, T., Larsson, M. C., Miwa, J., Maule, A. G., Sahashi, N., Jones, J. T. and Berriman, M. (2011). Genomic insights into the origin of parasitism in the emerging plant pathogen Bursaphelenchus xylophilus. PLOS Pathogenesis 7, e1002219. doi: 10.1371/journal.ppat. 1002219

Koutsovoulos, G., Makepeace, B., Tanya, V. and Blaxter, M. (2014) Palaeosymbiosis revealed by genomic fossils of Wolbachia in a strongyloidean nematode. PLOS Genetics 10, e1004397. doi: 10.1371/journal. pgen.1004397.

Kumar, S., Koutsovoulos, G., Kaur, G. and Blaxter, M. (2012a). Toward 959 nematode genomes. Worm 1, 1-9.

Kumar, S., Schiffer, P.H. and Blaxter, M. (2012b). 959 Nematode genomes: a semantic wiki for coordinating sequencing projects. Nucleic Acids Research 40, D1295-1300. doi: 10.1093/nar/gkr826.

Laetsch, D. R., Heitlinger, E. G., Taraschewski, H., Nadler, S. A. and Blaxter, M. L. (2012). The phylogenetics of Anguillicolidae (Nematoda: Anguillicolidea), swimbladder parasites of eels. BMC Evolutionary Biology 12, 60. doi: 10.1186/1471-2148-12-60.

Laing, R., Kikuchi, T., Martinelli, A., Tsai, I. J., Beech, R. N., Redman, E., Holroyd, N., Bartley, D. J., Beasley, H., Britton, C., Curran, D., Devaney, E., Gilabert, A., Hunt, M., Jackson, F., Johnston, S. L., Kryukov, I., Li, K., Morrison, A. A., Reid, A. J., Sargison, N., Saunders, G. I., Wasmuth, J. D., Wolstenholme, A., Berriman, M., Gilleard, J. S. and Cotton, J. A. (2013). The genome and transcriptome of Haemonchus contortus, a key model parasite for drug and vaccine discovery. Genome Biology 14, R88. doi: 10.1186/gb-2013-14-8-r88. Lambshead, P. J. D. (1993). Recent developments in marine benthic biodiversity research. Oceanis 19, 5-24.

Landmann, F., Voronin, D., Sullivan, W. and Taylor, M. J. (2011) Anti-filarial activity of antibiotic therapy is due to extensive apoptosis after Wolbachia depletion from filarial nematodes. PLOS Pathogenesis $\mathbf{7}$, e1002351. doi: 10.1371/journal.ppat.1002351

Landmann, F., Bain, O., Martin, C., Uni, S., Taylor, M. J. and Sullivan, W. (2012). Both asymmetric mitotic segregation and cell-to-cell invasion are required for stable germline transmission of Wolbachia in filarial nematodes. Biology Open 1, 536-547. doi: 10.1242/bio.2012737.

Lartillot, N., Lepage, T. and Blanquart, S. (2009). PhyloBayes 3: a Bayesian software package for phylogenetic reconstruction and molecular dating. Bioinformatics 25, 2286-2288. doi: 10.1093/bioinformatics/btp368. Li, L., Stoeckert, C. J., Jr. and Roos, D. S. (2003). OrthoMCL: identification of ortholog groups for eukaryotic genomes. Genome Research 13, 2178-2189.

Lo, N., Casiraghi, M., Salati, E., Bazzocchi, C. and Bandi, C. (2002). How many Wolbachia supergroups exist? Molecular Biology and Evolution 19, 341-346.

Lunt, D. H., Kumar, S., Koutsovoulos, G. and Blaxter, M. L. (2014). The complex hybrid origins of the root knot nematodes revealed through comparative genomics. peerf 6, e356 doi: 10.7717/peerj.356.

Mayer, W. E., Schuster, L. N., Bartelmes, G., Dieterich, C. and Sommer, R. J. (2011). Horizontal gene transfer of microbial 
cellulases into nematode genomes is associated with functional assimilation and gene turnover. BMC Evolutionary Biology 11, 13. doi: 10.1186/14712148-11-13.

McNulty, S. N., Fischer, K., Curtis, K. C., Weil, G. J., Brattig, N. W. and Fischer, P. U. (2013). Localization of Wolbachia-like gene transcripts and peptides in adult Onchocerca flexuosa worms indicates tissue specific expression. Parasitology Vectors 6, 2. doi: 10.1186/1756-3305-6-2.

Meldal, B. H., Debenham, N. J., De Ley, P., De Ley, I. T., Vanfleteren, J. R., Vierstraete, A. R., Bert, W., Borgonie, G., Moens, T., Tyler, P. A., Austen, M. C., Blaxter, M. L., Rogers, A. D. and Lambshead, P. J. (2007). An improved molecular phylogeny of the Nematoda with special emphasis on marine taxa. Molecular Phylogenetics and Evolution 42, 622-636.

Mitreva, M., Smant, G. and Helder, J. (2009). Role of horizontal gene transfer in the evolution of plant parasitism among nematodes. Methods in Molecular Biology 532, 517-535. doi: 10.1007/978-1-60327-853-9_30.

Mitreva, M., Jasmer, D. P., Zarlenga, D. S., Wang, Z., Abubucker, S., Martin, J., Taylor, C. M., Yin, Y., Fulton, L., Minx, P., Yang, S. P., Warren, W. C., Fulton, R. S., Bhonagiri, V., Zhang, X., HallsworthPepin, K., Clifton, S. W., McCarter, J.P., Appleton, J., Mardis, E. R. and Wilson, R. K. (2011). The draft genome of the parasitic nematode Trichinella spiralis. Nature Genetics 43, 228-235. doi: 10.1038/ng.769.

Moravec, F. and de Buron, I. (2013). A synthesis of our current knowledge of philometrid nematodes, a group of increasingly important fish parasites. Folia Parasitologica (Praha) 60, 81-101

Mortazavi, A., Schwarz, E. M., Williams, B., Schaeffer, L., Antoshechkin, I., Wold, B. J. and Sternberg, P. W. (2010). Scaffolding a Caenorhabditis nematode genome with RNA-seq. Genome Research 20, 1740-1747. doi: 10.1101/gr.111021.110.

Murfin, K. E., Dillman, A. R., Foster, J. M., Bulgheresi, S. Slatko, B. E., Sternberg, P. W. and Goodrich-Blair, H. (2012). Nematode-bacterium symbioses - cooperation and conflict revealed in the "omics" age. Biological Bulletin 223, 85-102.

Nadler, S. A., Carreno, R. A., Mejia-Madrid, H., Ullberg, J., Pagan, C., Houston, R. and Hugot, J. P. (2007). Molecular phylogeny of clade III nematodes reveals multiple origins of tissue parasitism. Parasitology 134, 1421-1442.

Nielsen, C. (2001). Animal Evolution. Interrelationships of the Living Phyla, 2nd Edn. Oxford University Press, Oxford, UK.

O'Neill, S.L. (1995). Wolbachia pipientis: symbiont or parasite? Parasitology Today 11, 168-169.

Opperman, C. H., Bird, D. M., Williamson, V. M., Rokhsar, D. S., Burke, M., Cohn, J., Cromer, J., Diener, S., Gajan, J., Graham, S., Houfek, T. D., Liu, Q., Mitros, T., Schaff, J., Schaffer, R., Scholl, E., Sosinski, B. R., Thomas, V.P. and Windham, E. (2008). Sequence and genetic map of Meloidogyne hapla: a compact nematode genome for plant parasitism. Proceedings of the National Academy of Sciences USA 105, 14802-14807. doi: 10.1073/pnas.0805946105.

Park, J. K., Sultana, T., Lee, S. H., Kang, S., Kim, H. K., Min, G. S., Eom, K. S. and Nadler, S. A. (2011). Monophyly of clade III nematodes is not supported by phylogenetic analysis of complete mitochondrial genome sequences. BMC Genomics 12, 392. doi: 10.1186/1471-2164-12-392.

Parkinson, J. and Blaxter, M. (2003). SimiTri - visualizing similarity relationships for groups of sequences. Bioinformatics 19, 390-395.

Parkinson, J., Mitreva, M., Whitton, C., Thomson, M., Daub, J., Martin, J., Schmid, R., Hall, N., Barrell, B., Waterston, R.H., McCarter, J. P. and Blaxter, M. L. (2004). A transcriptomic analysis of the phylum Nematoda. Nature Genetics 36, 1259-1267.

Parra, G., Bradnam, K. and Korf, I. (2007). CEGMA: a pipeline to accurately annotate core genes in eukaryotic genomes. Bioinformatics 23, 1061-1067. doi: 10.1093/bioinformatics/btm071

Pierantoni, U. (1916). I Nematodi parassiti degli Oligocheti. Bollettino della Società dei naturalisti in Napoli 28, 139-163.

Platonova, T. A. and Gal'tsova, V. V. (1976). Nematodes and their Role in the Meiobenthos. Nakua, Leningrad.

Poulin, R. (2011). The many roads to parasitism: a tale of convergence. Advances in Parasitology 74, 1-40. doi: 10.1016/B978-0-12-3858979.00001-X

Poulin, R. and Randhawa, H.S. (2013). Evolution of parasitism along convergent lines: from ecology to genomics. Parasitology 11, 1-10. doi: 10.1017/S0031182013001674

Read, A. F. and Skorping, A. (1995a). Causes and consequences of life history variation in parasitic nematodes. In Ecology and Transmission Strategies of Entomopathogenic Nematodes (COST 819) (ed. Griffin, C. T., Gwynn, R. L. and Masson, J. P.), pp. 58-68. European Commission, Brussels, Belgium.

Read, A. F. and Skorping, A. (1995b). The evolution of tissue migration by parasitic nematode larvae. Parasitology 111, 359-371.
Richter, S. (1993). Phoretic association between the dauerjuveniles of Rhabditis stammeri (Rhabditidae) and life history stages of the burying beetle Nicrophorus vespilloides (Coleoptera: Silphidae). Nematologica 39. 346-355.

Rybarczyk-Mydlowska, K., Maboreke, H. R., van Megen, H., van den Elsen, S., Mooyman, P., Smant, G., Bakker, J. and Helder, J. (2012). Rather than by direct acquisition via lateral gene transfer, GHF5 cellulases were passed on from early Pratylenchidae to rootknot and cyst nematodes. BMC Evolutionary Biology 12, 221. doi: 10.1186/ 1471-2148-12-221.

Schiffer, P. H., Kroiher, M., Kraus, C., Koutsovoulos, G. D., Kumar, S., Camps, J. I., Nsah, N.A., Stappert, D., Morris, K., Heger, P., Altmuller, J., Frommolt, P., Nurnberg, P., Thomas, W. K., Blaxter, M. L. and Schierenberg, E. (2013). The genome of Romanomermis culicivorax: revealing fundamental changes in the core developmental genetic toolkit in Nematoda. BMC Genomics 14, 923. doi: 10.1186/1471-2164-14-923.

Schmidt-Rhaesa, A. (1997). Phylogenetic relationships of the Nematomorpha - a discussion of current hypotheses. Zoologischer Anzeiger, Fena 236, 203-216.

Skorping, A., Read, A. F. and Keymer, A.E. (1991). Life history covariation in intestinal nematodes of mammals. Oikos 60, 365-372.

Smant, G., Stokkermans, J.P., Yan, Y., de Boer, J. M., Baum, T. J., Wang, X., Hussey, R. S., Gommers, F. J., Henrissat, B., Davis, E. L., Helder, J., Schots, A. and Bakker, J. (1998). Endogenous cellulases in animals: isolation of beta-1, 4-endoglucanase genes from two species of plant-parasitic cyst nematodes. Proceedings of the National Academy of Sciences USA 95, 4906-4911.

Srinivasan, J., Dillman, A. R., Macchietto, M. G., Heikkinen, L., Lakso, M., Fracchia, K. M., Antoshechkin, I., Mortazavi, A. Wong, G. and Sternberg, P.W. (2013). The draft genome and transcriptome of Panagrellus redivivus are shaped by the harsh demands of a free-living lifestyle. Genetics 193, 1279-1295. doi: 10.1534/genetics.112. 148809

Stein, L. D., Bao, Z., Blasiar, D., Blumenthal, T., Brent, M. R., Chen, N., Chinwalla, A., Clarke, L., Clee, C., Coghlan, A. Coulson, A., D'Eustachio, P., Fitch, D. H., Fulton, L.A., Fulton, R. E., Griffiths-Jones, S., Harris, T. W., Hillier, L. W. Kamath, R., Kuwabara, P.E., Mardis, E. R., Marra, M. A., Miner, T.L., Minx, P., Mullikin, J.C., Plumb, R. W., Rogers, J., Schein, J.E., Sohrmann, M., Spieth, J., Stajich, J. E., Wei, C., Willey, D., Wilson, R. K., Durbin, R. and Waterston, R.H. (2003). The genome sequence of Caenorhabditis briggsae: a platform for comparative genomics. PLOS Biology 1, E45.

Sudhaus, W. (Ed.) (2008). Evolution of Insect Parasitism in Rhabditid and Diplogastrid Nematodes. SASA, Belgrade \& UNESCO MAB Serbia, Vienna, Austria.

Sudhaus, W. (2010). Preadaptive plateau in Rhabditida (Nematoda) allowed the repeated evolution of zooparasites, with an outlook on evolution of life cycles within Spiroascarida. Palaeodiversity 3 (Suppl.), 117-130.

Sultana, T., Kim, J., Lee, S.H., Han, H., Kim, S., Min, G.S., Nadler, S. A. and Park, J. K. (2013). Comparative analysis of complete mitochondrial genome sequences confirms independent origins of plantparasitic nematodes. Evolutionary Biology 13, 12. doi: 10.1186/1471-2148$13-12$

The C. elegans Genome Sequencing Consortium (1998). Genome sequence of the nematode $C$. elegans: a platform for investigating biology. Science 282, 2012-2018.

Vandekerckhove, T. T., Willems, A., Gillis, M. and Coomans, A. (2000). Occurrence of novel verrucomicrobial species, endosymbiotic and associated with parthenogenesis in Xiphinema americanum-group species (Nematoda, Longidoridae). International Fournal of Systematic and Evolutionary Microbiology 50, 2197-2205.

van Megen, H., van den Elsen, S., Holterman, M., Karssen, G., Mooyman, P., Bongers, T., Holovachov, O., Bakker, J. and Helder, J. (2009). A phylogenetic tree of nematodes based on about 1200 full-length small subunit ribosomal DNA sequences. Nematology 11, 927-950.

Wang, J., Mitreva, M., Berriman, M., Thorne, A., Magrini, V. Koutsovoulos, G., Kumar, S., Blaxter, M. L. and Davis, R. E. (2012). Silencing of germline-expressed genes by DNA elimination in somatic cells Developmental Cell 23, 1072-1080. doi: 10.1016/j.devcel.2012.09.020.

Werren, J. H. (1997). Biology of Wolbachia. Annual Reviews of Entomology 42, 587-609.

Wu, B., Novelli, J., Jiang, D., Dailey, H. A., Landmann, F., Ford, L., Taylor, M. J., Carlow, C. K., Kumar, S., Foster, J. M. and Slatko, B. E. (2013). Interdomain lateral gene transfer of an essential ferrochelatase gene in human parasitic nematodes. Proceedings of the National Academy of Sciences USA 110, 7748-7753. doi: 10.1073/pnas.1304049110. 